\title{
EFEKTIVITAS PEMBERLAKUAN TARIF PROGRESIF BAGI PAJAK KENDARAAN BERMOTOR GUNA MENINGKATKAN PENERIMAAN PAJAK
}

\author{
Ida Bagus Agung Daparhita(1), A.A.A. Ngr. Tini Rusmini Gorda(2) \\ agungdaparhita@gmail.com, admisi@pasca-undiknas.ac.id \\ Undiknas University, Denpasar, Bali
}

\begin{abstract}
Motor Vehicle Tax (PKB) is one type of tax whose authority of collection is on Provincial government as a form of autonomy implementation. Nevertheless the government through Law no. 28 Year 2009 on Regional Tax and Retribution has been applying progressive tariff for motor vehicle taxation (PKB). Government policy is related to the purpose of increasing local tax revenues from the PKB sector. The provincial government further implements the policy by issuing local regulations concerning the implementation of progressive taxation, among which regulates the amount of tax to be imposed on each motor vehicle. In Bali Province Regulation no. 1 Year 2011 on Regional Taxes, the provincial government of Bali has set the tax rate between $1.5 \%$ to $7.5 \%$. In addition to the increase in tax revenues, the progressive tariff for PKB also aims to reduce people's purchasing power on motor vehicles. This is investigates whether it is possible to increase tax revenues when the purchasing power of people to buy motor vehicles goes down. This research is conducted by empirical research method, in order to study the effectiveness of progressive tariff policy for motor vehicle to increase tax revenue from PKB in Bali Province area. This research uses actual data related to the amount of PKB receipt obtained since before the enactment of progressive tariff until several years after. Based on these data, it can be seen the effectiveness of the implementation of the progressive tariff. In addition, it will also convey the obstacles faced by the Bali Provincial Government in implementing the progressive tariff policy of PKB. Thus the research will be able to give description of the enforcement of progressive rate of PKB as well as to formulate suggestions to reduce the constraints of its implementation, especially in the area of Bali Province.
\end{abstract}

Keywords: Revenue, Progressive Rate, Motor Vehicle.

\section{ABSTRAK}

Pajak Kendaraan Bermotor (PKB) merupakan salah satu jenis pajak yang kewenangan pemungutannya ada pada pemerintah daerah Provinsi, sebagai bentuk pelaksanaan otonomi. Meskipun demikian pemerintah melalui Undang-Undang No. 28 Tahun 2009 tentang Pajak Daerah dan Retribusi Derah membentuk kebijakan menerapkan tarif progresif bagi pemungutan pajak kendaraan bermotor (PKB). Kebijakan pemerintah tersebut berkaitan dengan tujuan meningkatkan penerimaan pajak daerah dari sektor PKB. Pemerintah daerah provinsi selanjutnya melaksanakan kebijakan tersebut dengan menerbitkan peraturan daerah mengenai pelaksanaan pajak progresif, yang diantaranya mengatur besaran pajak yang akan dikenakan bagi setiap kendaraan bermotor. Dalam Perda Provinsi Bali No. 1 Tahun 2011 tentang Pajak Daerah, pemerintah provinsi Bali telah menetapkan besaran tarif pengenaan pajak antara $1,5 \%$ sampai dengan $7,5 \%$. Selain peningkatan penerimaan pajak, tarif progresif bagi PKB bertujuan pula untuk menurunkan daya beli masyarakat terhadap 
kendaraan bermotor. Hal inilah yang menjadi kajian apakah mungkin meningkatkan penerimaan pajak ketika daya beli masyarakat untuk membeli kendaraan bermotor turun. Penelitian ini dilaksanakan dengan metode penelitian empiris, yaitu mengkaji efektifitas kebijakan tarif progresif bagi kendaraan bermotor untuk meningkatkan penerimaan pajak dari PKB di wilayah Provinsi Bali. Sehingga dalam penelitian ini akan disajikan datadata factual terkait jumlah penerimaan PKB yang diperoleh sejak sebelum diberlakukannya tarif progresif hingga beberapa tahun setelahnya. Berdasarkan data tersebut dapat dilihat efektifitas keberlakuan tarif progresif tersebut. Selain itu akan disampaikan pula mengenai kendalakendala yang dihadapi pemerintah Provinsi Bali dalam menerapkan kebijakan tarif progresif PKB. Dengan demikian penelitian akan mampu memberikan gambaran keberlakuan tarif progresif PKB serta merumuskan saran untuk mengurangi kendala pemberlakuannya, khususnya di wilayah Provinsi Bali.

Kata Kunci: Penerimaan, Tarif Progresif, Kendaraan Bermotor

\section{PENDAHULUAN}

\section{Latar Belakang}

Pembangunan di Negara Indonesia sangat bergantung kepada sektor pajak, sebagai salah satu sumber pendapatan negara.Dalam pandangan Rachmat Soemitro, pajak merupakan iuran rakyat kepada kas Negara berdasarkan perundang-undangan yang bersifat paksaan dengan tiada mendapat balasjasayang tidak langsung dapat ditunjukkan dan dipergunakan untuk membiayai pengeluaran umum negara. ${ }^{1}$ Pemungutan pajak oleh negara dalam rangka mewujudkan kesejahteraan rakyat merupakan pemikiran yang bersumber dari konsep negara kesejahteraan (welfare state).

Pajak yang diperoleh pemerintah berdasarkan lembaga atau instansi yang memungut pajak serta pengelolaannya dibagi menjadi dua, yaitu pajak pusat dan pajak daerah. Pajak pusat memiliki delapan jenis pajak, sedangkan pajak daerah diklasifikasikan lagi menjadi pajak daerah provinsi sejumlah lima jenis pajak, dan sebelas pajak kabupaten/kota. ${ }^{2}$ Melalui Undang-Undang Nomor 28 Tahun 2009 tentang Pajak Daerah dan Retribusi Daerah (selanjutnya disingkat UU Pajak Daerah dan Retribusi Daerah), pemerintah pusat mengalihkan beberapa pajak yang semula ditarik oleh pusat menjadi pajak daerah.

1Tony Marsyahrul, 2014, Pengantar Perpajakan, Grasindo, Jakarta, h.2.

2Safri Nurmantu, 2007, Pengantar Perpajakan, Edisi 3, Granit, Jakarta, h. 
Pajak daerah merupakan iuran wajib yang dilakukan oleh orang pribadi atau badan kepada daerah tanpa imbalan langsung yang seimbang, yang dapat dipaksakan berdasarkan peraturan perundangundangan yang berlaku, yang digunakan untuk membiayai penyelenggaraan pemerintahan daerah dan pembangunan daerah.Selain itu pajak daerah diharapkan menjadi salah satu sumber pembiayaan untuk meningkatkan dan meeratakan kesejahteraan daerah. Pajak daerah ini merupakan salah satu konsekuensi logis dengan diterapkannya otonomi daerah yang mewajibkan daerah untuk mampu mengatur dan mengurus rumah tangganya sendiri. ${ }^{3}$

Salah satu jenis pajak daerah yang merupakan sumber pendapatan terbesar dari sektor pajak adalah pajak kendaraan bermotor yaitu pajak atas kepemilikan dan/atau penguasaan atas kendaraan bermotor. Pajak kendaraan bermotor ini sangat berpengaruh terhadap sumber pendapatan asli daerah, yang berguna untuk membiayai pelaksanaan tugas rutin pemerintah daerah. Hasil pemungutan pajak kendaraan bermotor ini berfungsi untuk pembangunan daerah Provinsi yang selanjutnya diserahkan kepada kabupaten/kota dana perimbangan dalam bentuk Dana Bagi Hasil.

Pengenaan pajak kendaraan bermotor di wilayah Provinsi Bali diatur dalam Pemerintah Peraturan Daerah Provinsi Bali No. 1 Tahun 2011 tentang Pajak Daerah, sebagaimana telah dirubah dengan Peraturan Daerah Provinsi Bali No. 8 Tahun 2016 (selanjutnya disingkat dengan Perda No. 8 Tahun 2016). Perda No. 8 Tahun 2016 merupakan peraturan pelaksana di daerah atas ketentuan yang terdapat dapat UU Pajak Daerah dan Retribusi Daerah yang menentukan pengenaan pajak progresif terhadap kendaraan bermotor. Dalam Perda No. 8 Tahun 2016 tersebut ditentukan mengenai tarif pajak progresif bagi kendaraan bermotor dikenakan untuk kendaraan bermotor kedua dan seterusnya yang didasarkan atas nama dan alamat pemilik kendaraan yang sama. Harapan pemerintah melalui penerapan pajak progresif ini mampu mengurangi jumlah kepemilikan kendaraan bermotor pribadi dan secara tidak langsung diharapkan pula dapat mengurangi kemacetan yang diakibatkan oleh 
padatnya kendaraan bermotor pribadi.

Bedasarkan hasil pengamatan, pengenaan pajak progresif bagi kendaraan bermotor ini memiliki impikasi kepada wajib pajak yaitu pemilik kendaraan pribadi harus membayar pajak lebih mahal untuk kepemilikan kendaraan yang kedua dan seterusnya, yang dikarenakan ada peningkatan tarif pengenaan pajak. Sementara itu bagi pemerintah pengenaan pajak progresif bagi kendaraan bermotor berimplikasi bagi meningkatnya Pendapatan Asli Daerah yang diperoleh dari sektor pajak, khususnya Pajak Kendaraan Bermotor.Berdasarkan hal tersebut maka menjadi hal yang menarik untuk dikaji mengenai efektivitas penerapan pajak progresif dalam meningkatkan pendapatan daerah, khususnya dari pajak kendaraan bermotor.

\section{TINJAUAN PUSTAKA}

\section{Konsepsi Pajak}

Pengertian pajak menurut Rochmat Soemitro yaitu pajak adalah iuran rakyat kepada Negara berdasarkan Undang-Undang (yang dapat dipaksakan) dengan tidak dapat jasa timbal balik (konsentrasi), yang langsung dapat ditunjukan dan yang digunakan untuk membayar pengeluaran umum. ${ }^{4}$ Sementara Sommerfeld mendefinisikan pajak sebagai suatu pengalihan sumber-sumber yang wajib dilakukan dari sektor swasta kepada sektor pemerintah berdasarkan peraturan tanpa suatu imbalan kembali yang langsung dan seimbang, agar pemerintah dapat melaksanakan tugas-tugasnya dalam menjalankan pemerintahan. ${ }^{5}$

Keberadaan pajak dalam suatu negara memiliki 2 (dua) fungsi yaitu fungsi budgeter dan fungsi regulerend. Pajak memiliki fungsi budgeter disebut sebagai fungsi utama pajak atau fungsi fiskalyaitu suatu fungsi dimana pajak digunakan sebagai alat untuk memasukkan dana secara optimal ke kas negara sesuai dengan peraturan perundang-undangan yang berlaku. Fungsi ini merupakan alasan utama negara dalam memungut pajak terhadap warganya, yaitu bahwa dalam berbagai kegiatan penyelenggaraan negara oleh pemerintah dibutuhkan biaya yang diperoleh

h. 1 .

${ }^{4}$ Mardiasmo, 2013, Perpajakan(edisi revisi), CV. Andi Offset,Yogyakarta, ${ }^{5}$ lbid. 
dengan jalan memungut pajak secara optimal kepada warganya. Sementara fungsi regulerend menunjukkan fungsi pajak sebagai sarana untuk mengatur keadaan dalam masyarakat pada bidang, sosial, ekonomi, maupun politik sesuai dengan kebijakan yang diambil pemerintah. Contoh: dikenakannya pajak yang lebih tinggi terhadap minuman keras, ketersediaan minuman keras dapat ditekan, demikian pula dengan barang mewah. ${ }^{6}$

Pemungutan pajak oleh pemerintah suatu negara kepada warganya bertujuan untuk mengisi kas negara yang akan digunakan untuk membiayai kegiatan pemerintahan negara dalam upaya menyejahterakan rakyat. Selain pandangan tersebut, dasar pengenaan pajak kepada warga juga dapat dijelaskan melalui beberapa teori yaitu teori asuransi, teori kepentingan, teori gaya pikul, teori gaya beli, dan teori bakti. ${ }^{7}$

1) Teori Asuransi

Dalam teori asuransi pembayaran pajak disamakan dengan iuran atau premi yang wajib dibayarkan peserta suatu asuransi. Premi yang dibayarkan setiap bulan tersebut merupakan angsuran perlindungan bagi pesertanya atas keselamatan diri dan harta bendanya. Apabila salah satu peserta asuransi mengalami resiko keselamatan atas diri dan harta bendanya, maka pihak asuransi akan membayarkan klaim asuransi yang dananya dikumpulkan dari premi yang dibayar peserta asuransi lainnya.

2) Teori Kepentingan

Teori kepentingan mendalilkan pembebanan pajak kepada warga negara didasarkan atas besarnya kepentingan masyarakat dalam suatu negara. Kepentingan tersebut antara lain berupa perlindungan masyarakat atas jiwa dan hartanya yang harus diselenggarakan oleh pemerintah. Oleh karena itu menjadi suatu kewajaran apabila pengeluaran negara untuk memberikan perlindungan tersebut dibebankan kepada masyarakat melalui pembayaran pajak.

3) Teori Daya Pikul

Teori daya pikul menjelaskan pemungutan pajak sebagai biaya yang harus dipikul oleh setiap orang yang menikmati perlindungan yang

${ }^{6}$ Safri Nurmantu, Op. Cit., hal. 30.

7 Supramono dan Theresia Woro Damayanti, 2013, Perpajakan Indonesia, Mekanisme dan Perhitungannya, Andi Offset, Yogyakarta, h. 2. 
diberikan negara, yang dibayarkan dalam bentuk pajak. Berdasarkan pada nilai-nilai keadilan distributif, pajak yang dikenankan kepada masyarakat tergantung dari daya pikul masing-masing anggota masyarakat, masyarakat dengan penghasilan lebih tinggi memiliki kewajiban membayar pajak (daya pikul) yang besar juga.

\section{4) Teori Bakti}

Teori bakti beranggapan bahwa masyarakat memiliki kewajiban mutlak kepada negara yang ditunjukkan melalui kewajiban membayar pajak sehingga menjadi hak mutlak dari negara untuk memungut pajak kepada warganya.

5) Teori Asas Daya Beli

Teori ini berpandangan pemungutan pajak oleh pemerintah dipergunakan dalam rangka menarik daya beli masyarakat. Pajak yang dipungut oleh pemerintah secara tidak langsung akan mengurangi jumlah penghasilan yang diperoleh warga untuk konsumsi, sehingga akibat yang ditimbulkan dari pemungutan pajak adalah daya beli masyarakat akan berkurang secara individu. Selanjutnya negara akan menyalurkan kembali daya beli masyarakat yang sudah dikurangi kepada masyarakat melalui upaya peningkatan kesejahteraan nasional.

\section{Teori Kebijakan}

Setiap tindakan yang diambil pemerintah, baik berbuat maupun tidak berbuat, sering disebut dengan kebijakan yang berasal dari kata policy dalam bahasa Inggris. Kebijakan dalam Kamus Besar Bahasa Indonesia diartikan sebagai suatu rangkaiankonsep yang menjadi dasar rencana dalampelaksanaan suatu pekerjaan, kepemimpinan, dan cara bertindak (tentang pemerintahan, organisasi, dsb). Kebijakan dapat pula diartikan sebagai garis pedoman untuk manajemen dalam usaha mencapai sasaran.

Kebijakan dalam pandangan Carl Frederich merupakan tindakan atau kegiatan yang diusulkan seseorang/kelompok atau pemerintah dalam suatu lingkungantertentu dimana terdapat hambatan-hambatan (kesulitankesulitan) dankesempatan-kesempatan terhadap pelaksanaan usulan kebijaksanaantersebut dalam rangka mencapai tujuan tertentu. Pandangan Frederich ini menunjukan bahwa kebijakan melibatkan perilaku yang memilikimaksud dan tujuan, sehinggasuatu kebijakan harus 
memuat hal yang dikerjakan daripada usulan dalam beberapa kegiatan untuk memecahkan suatu masalah. ${ }^{8}$

James E. Anderson mengungkapkan keijakan sebagai serangkaian tindakan yang mempunyai tujuan tertentu yang diikuti dan dilaksanakan oleh seorang pelaku atau sekelompok pelaku guna memecahkan suatu masalah tertentu. ${ }^{9}$ Berdasarkan beberapa pandangan tersebut maka dapat disimpulkan bahwa kebijakan menunjukkan adanya suatu kegiatan demi mencapai tujuan, berbeda dengan keputusan yaitu pilihan diantara berbagai alternatif tindakan. Dengan demikian kebijakan adalah tindakantindakan dilakukan atau tidak dilakukan secara sengaja oleh pemerintah, yang di dalamnya terdapat unsur keputusan guna mencapai maksuddan tujuan tertentu.

Kebijakan berkaitan juga dengan adanya kewajiban pemerintah untuk melakukan bestuuruzorg atau public service yakni penyelenggaraan kepentingan umum. ${ }^{10}$ Demikian halnya dengan pemungutan pajak merupakan suatu kebijakan yang diambil oleh pemerintah. Kebijakan mengenai pemungutan pajak progresif terhadap kendaraan bermotor merupakan suatu rangkaian kegiatan yang bertujuan untuk meningakatkan Pendapatan Asli Daerah guna membantu keuangan daerah dalam membiayai pemerintahannya. Meningkatnya pendapatan daerah diharapkan mampu memberikan kemandirian daerah dalam hal pengelolaan keuangan. Otonomi daerah tidak hanya diartikan sebagai kewenangan untuk menyelenggarakan pemerintahan secara mandiri, namun juga kemandirian mengelola keuangan daerah guana membiayai segala kegiatan pemerintahannya. Tujuan sampingan dari penerapan pajak progresif tentunya agar masyarakat secara berangsur mengurangi jumlah kepemilikan kendaraan bermotornya, dengan meningkatnya beban pajak kendaraan bermotor yang harus dibayarkan. Hal ini merupakan salah satu solusi mengurangi kemacetan disamping menambah ruas jalan untuk mengimbangi jumlah kendaraan bermotor.

\section{Teori Efektivitas Keberlakuan Hukum}

Soerjono Soekanto menyatakan bahwa untuk dapat terlaksananya

\footnotetext{
${ }^{8}$ Leo Agustino, 2008, Dasar-Dasar Kebijakan Publik, Alfabeta, Bandung, h. 7.

${ }^{9}$ M. Irfan Islamy, 2009, Prinsip-Prinsip Perumusan Kebijaksanaan Negara, Bumi Aksara, Jakarta, h. 17.

10 Marbun, SF \& Mahfud MD, Moh, 2006, Pokok-Pokok Hukum Administrasi Negara, Liberty Yogyakarta, h. 46.
} 
suatu peraturan perundang-undangan secara efektif, dipengaruhi oleh beberapa faktor yaitu sebagai berikut: ${ }^{11}$

a. Faktor hukumnya sendiri

b. Faktor penegak hukum, yakni pihak-pihak yang membentuk maupun menerapkan hukum.

c. Faktor sarana atau fasilitas yang mendukung penegak hukum.

d. Faktor masyarakat, yakni lingkungan dimana hukum tersebut berlaku atau diterapkan.

e. Faktor kebudayaan, yakni sebagai hasil karya, cipta dan rasa yang didasarkan pada karsa manusia di dalam pergaulan hidup.

Faktor-faktor tersebut di atas saling berkaitan erat satu sama lain, sebab merupakan esensi dari penegakan hukum, juga merupakan tolak ukur dari efektivitas berlakunya undang-undang atau peraturan. Kelima faktor tersebut dapat dikaji berdasarkan Teori Sistem Hukum dari Lawrence M. Friedman. Teori sistem hukum dari Lawrence M. Friedman menyatakan: bahwa sebagai suatu sistem hukum dari sistem kemasyarakatan, maka hukum mencakup tiga komponen yaitu: ${ }^{12}$

a. legal substance (substansi hukum); merupakan aturan-aturan, norma-norma dan pola perilaku nyata manusia yang berada dalam sistem, termasuk produk yang dihasilkan oleh orang yang berada di dalam sistem hukum itu, mencakup keputusan yang mereka keluarkan atau aturan baru yang mereka susun.

b. legal structure (struktur hukum); merupakan kerangka, bagian yang tetap bertahan, bagian yang memberikan semacam bentuk dan batasan terhadap keseluruhan instansi-instansi penegak hukum. Di Indonesia yang merupakan struktur dari sistem hukum antara lain; institusi atau penegak hukum seperti advokat, polisi, jaksa dan hakim.

c. legal culture (budaya hukum); merupakan suasana pikiran sistem dan kekuatan sosial yang menentukan bagaimana hukum itu digunakan, dihindari atau disalahgunakan oleh masyarakat.

Ketiga komponen-komponen dalam sistem yang saling

${ }^{11}$ Soerjono Soekanto, 2000, Penelitian Hukum Normatif: Suatu Tinjauan Singkat, edisi 1, cet.v, PT Raja Grafindo Persada, Jakarta, hal. 15.

12 Lawrence M. Friedman, 1969, The Legal System: A Sosial Science Perspective. Russel Sage Foundation, New York, h. 16. 
mempengaruhi satu sama lainnya tersebut, maka dapat dikaji bagaimana bekerjanya hukum dalam praktek sehari-hari. Hukum merupakan budaya masyarakat, oleh karena itu tidak mungkin mengkaji hukum secara satu atau dua sistem hukum saja, tanpa memperhatikan kekuatan-kekuatan sistem yang ada dalam masyarakat. Dengan demikian teori sistem hukum ini menganalisa masalah-masalah terhadap penerapan substansi hukum, struktur hukum dan budaya hukum.

\section{METODE PENELITIAN}

\section{Lokasi Penelitian}

Penelitian mengenai pemberlakuan pajak progresif bagi kendaraan bermotor ini dilakukan di wilayah Kota Denpasar, khususnya melalui Unit Pelaksana Teknis Badan Pendapatan Daerah (UPT Bapenda) Provinsi Bali di Kota Denpasar. Penelitian dilakukan di Kota Denpasar dengan pertimbangan bahwa Kota Denpasar merupakan Ibu Kota Provinsi yang sering kali dijadikan acuan (pilot project) dalam pemberlakuan suatu instrumen peraturan perundang-undangan, dimana dalam hal ini akan dijadikan acuan pemberlakuan pajak progresif bagi kendaraan bermotor. Selain itu UPT Bapenda Provinsi Bali di Kota Denpasar merupakan UPT terbesar yang memiliki jumlah wajib pajak terbanyak se kabupaten/kota di Bali, sehingga UPT Bapenda Provinsi Bali di Kota Denpasar merupakan penyumbang terbesar bagi jumlah pendapatan Provinsi Bali dari pajak kendaraan bermotor.

\section{Desain Penelitian}

1. Tahap persiapan : Penelitian difokuskan untuk mengkaji efektivitas pemberlakuan pajak progresif bagi kendaraan bermotor bagi peningkatan Pendapatan Asli Daerah Provinsi Bali dari sektor pajak.

2. Tahap Lapangan : menentukan wilayah yang menjadi fokus penelitian yaitu di Kota Denpasar berdasarkan data yang diperoleh melalui UPT Bapenda Provinsi Bali di Kota Denpasar. 
Jenis penelitian yang digunakan adalah jenis penelitian hukum empiris. Menurut Rony Hanitijo Soemitro, penelitian hukum empiris atau penelitian hukum sosiologis, yaitu penelitian hukum yang memperoleh data dari sumber data primer. ${ }^{13}$ penelitian empiris ini dilakukan dengan cara melihat pelaksanaan penetapan pajak progresif bagi kendaraan roda 4 (empat). Pajak progresif dikenakan bagi wajib pajak yang memiliki kendaraan lebih dari satu. Pelaksanaan pajak progresif ini selanjutnya dikaitkan dengan tujuan penetapannya untuk meningkatkan Pendapatan Asli Daerah (PAD) dari sektor pajak, sehingga dapat diketahui apakah peraturan tersebut berlaku efektif atau tidak.

Sementara sumber data yang digunakan sebagai pendukung penulisan dalam penelitian ini yaitu :

\section{Sumber Data Primer}

Data primer adalah data yang diperoleh langsung dari masyarakat (mengenai perilakunya. ${ }^{14}$ Selain itu, data primer adalah data yang diperoleh langsung dari sumber pertama. ${ }^{15}$ Data primer diperoleh melalui teknik wawancara terstruktur kepada narasumber yang terkait dengan penelitian ini.Data primer dalam penelitian ini diperoleh dengan meneliti data atau laporan mengenai pendapatan yang diperoleh Pemerintah Provinsi Bali dari Pajak Kendaraan Bermotor (PKB). Hal ini dilakukan guna mencari data yang akurat untuk menunjang penelitian ini.

\section{Sumber Data Sekunder}

Data sekunder mencakup dokumen-dokumen resmi, buku-buku, hasil-hasil penelitian yang berwujud laporan, buku harian, dst. ${ }^{16}$ Selain itu, data sekunder adalah data yang diperoleh melalui dokumen-dokumen resmi, buku-buku, hasil penelitian yang berwujud laporan dan sebagainya. ${ }^{17}$ Data sekunder yang digunakan diperoleh dengan melakukan penelitian kepustakaan, yaitu dengan cara mengkaji bahan hukum yang memiliki keterkaitan dengan materi dalam penelitian ini serta untuk

${ }^{13}$ Soejono dan H.Abdurrahman, 2003, Metode Penelitian Hukum Cetakan Ke-2, PT. Rineka Cipta, Jakarta,hal.56.

${ }^{14} \mathrm{lbid}$, hal.51.

${ }^{15}$ Amiruddin dan H. Zainal Asikin, 2008, Op.cit, hal. 30.

${ }^{16} / \mathrm{bid}$, hal.12.

17 Soerjono Soekanto, Op.cit, hal. 12. 
menyempurnakan data lapangan. Adapun data sekunder yang digunakan dalam penelitian ini antara lain Undang-Undang Dasar Negara Republik Indonesia tahun 1945,Undang-Undang Nomor 28 Tahun 2009 tentang Pajak Daerah dan Retribusi Daerah,Peraturan Daerah Provinsi Bali No. 8 Tahun 2016 tentang Perubahan Kedua atas Peraturan Daerah Provinsi Bali No. 1 Tahun 2011 tentang Pajak Daerah.Selain itu menggunakan pula bahan hukum sekunder, yaitu bahan hukum yang berasal dari buku-buku yang bahasannya memiliki keterkaitan atau dapat menunjang penelitian yang dilakukan.

\section{Teknik Pengumpulan Data}

Teknik pengumpulan data yang digunakan yaitu dengan menggunakan teknik studi dokumen, pengamatan langsung, dan wawancara terstruktur kepada pejabat di lingkungan Badan Pendapatan Provinsi Bali dan UPT Badan Pendapatan Provinsi Bali Di Kota Denpasar. Teknik studi dokumen dilakukan terhadap sumber kepustakaan yang relevan dengan permasalahan penelitian dengan cara membaca dan mencatat kembali data yang kemudian dikelompokkan secara sistematis. Teknik wawancara dilakukan untuk memperoleh informasi langsung dari narasumber mengenai permasalahan yang diteliti. Dalam penelitian ini wawancara akan dilakukan kepada pejabat di lingkungan UPT Badan Pendapatan Provinsi Bali di Kota Denpasar mengenai efektivitas dan kendala-kendala yang dihadapi dalam pelaksanaan pajak progresif kendaraan bermotor. Selain itu wawancara juga bertujuan untuk memperoleh pendapat pejabat di lingkungan UPT Badan Pendapatan Provinsi Bali di Kota Denpasar, mengenai akibat hukum yang ditimbulkan apabila penerimaan PKB dan BBNKB kendaraan bermotor tidak sesuai target yang ditentukan, sehingga nantinya bisa mendapatkan informasi dan data yang pasti dan akurat.

\section{Teknik Pemeriksaan Keabsahan Data}

Keabsahan data yang dipergunakan dalam penelitian ini diperiksa melalui pengamatan yang berulang dan berkesinambungan dengan tujuan meningkatkan derajat kepercayaan data yang telah dikumpulkan dari responden serta semakin memfokuskan pada bidang yang akan dikaji. Selain itu pemeriksaan keabsahan data juga menggunakan teknik Triangulasi, dimana pemeriksaan data memanfaatkan 
hasil wawancara langsung terhadap pihak-pihak terkait, seperti pejabat dan staf di lingkungan UPT Bapenda Provinsi Bali di Kota Denpasar, serta wawancara terhadap wajib pajak langsung. Teknik triangulasi ini dilakukan dengan cara:

1. Membandingkan apa yang dikatakan orang di depan umum dengan apa yang dikatakan secara pribadi;

2. Membandingkan hasil wawancara dengan isi suatu dokumen yang saling berkaitan'

3. Mengadakan perbincangan dengan banyak pihak untuk mencapai pemahaman tentang suatu atau berbagai hal.

\section{Teknik Analisis Data}

Keseluruhan data yang telah didapat akan dianalisis secara kualitatif, yaitu dengan menggunakan metode observasi yang akan dilengkapi dengan wawancara terbatas terhadap beberapa responden yang kemudian disajikan secara deskriptif analisis dengan pemaparan bentuk uraian-uraian yang berhubungan dengan teori ataupun asas hukum yang terdapat dalam bidang ilmu hukum sehingga memperoleh suatu kesimpulan dan gambaran yang jelas dalam pembahasan masalah.

\section{PEMBAHASAN}

Keberadaan pajak sebagai sumber utama pendanaan pemerintahan merupakan hal yang tak dapat dipungkiri, dimana fungsi budgeter sebagai fungsi utama pajak. Peran sentral pajak tersebut tidak hanya ditemukan pada negara berkembang bahkan pada negara maju sekalipun pemungutan pajak merupakan suatu conditie sie qua non bagi upaya menambah keuangan negara, sebagaiman disampaikan Chaidir Ali. Tanpa adanya pemungutan pajak maka keuangan negara akan menjadi lumpuh, terlebih pada negara yang sedang membangun seperti di Indonesia. ${ }^{18}$

Demikian pula pentingnya pajak sebagai sumber pendanaan pemerintahan daerah, sehingga terdapat kewenangan pemerintah daerah untuk melakukan pemungutan pajak. Pelimpahan pemungutan pajak oleh pemerintah daerah dalam Undang-Undang PDRD memiliki tujuan untuk

${ }^{18}$ Bohari, 2016, Pengantar Hukum Pajak (Edisi Revisi), PT. Rajagrafindo Persada, Jakarta, h. 35. 
meningkatkan kemadirian daerah dan mengurangi ketergantungan pendanaan pemerintahan daerah terhadap pemerintah pusat. Dengan demikian otonomi daerah berdasarkan pola desentralisasi yang dianut dalam sistem pemerintahan Indonesia tidak hanya bersifat semu. Otonomi daerah tidak hanya hak menyelenggarakan pemerintahannya melainkan hak untuk mengelola pemerintahannya, termasuk dari segi keuangan daerah.

Berdasarkan pemungutan pajak yang menjadi kewenangan provinsi, maka PAD suatu daerah dari sektor pajak diperoleh dari Pajak Kendaraan Bermotor, Bea Balik Nama Kendaraan Bermotor, Pajak Bahan Bakar Kendaraan Bermotor, Pajak Air Permukaan, dan Pajak Rokok, sebagaimana ditetapkan dalam ketentuan Pasal 2 ayat (1) Undang-Undang PDRD. Selain pajak tersebut, dalam Pasal 6 ayat (1) Undang-Undang No. 33 Tahun 2004 tentang Perimbangan Keuangan Pusat dan Daerah (UU Perimbangan Keuangan Pusat-Daerah) sumber PAD daerah juga berasal dari pendapatan retribusi daerah, hasil pengelolaan kekayaan Daerah yang dipisahkan, dan lain-lain PAD yang sah. Dari berbagai sumber tersebut, hingga saat ini perolehan PAD daerah Provinsi Bali masih didominasi oleh pendapatan yang diperoleh dari pemungutan PKB dan BBNKB.

PKB merupakan pajak yang dikenakan kepada orang pribadi dan/atau badan atas kepemilikan dan/atau penguasaan kendaraan bermotor, sebagaimana dinyatakan dalam Undang-Undang PDRD. Ketentuan tersebut dimaknai Djafar Saidi memberikan 3 (tafsir) yaitu:

a. Subyek pajak memiliki kendaraan bermotor;

b. Subyek pajak memiliki dan menguasai kendaraan bermotor; dan

c. Subyek pajak hanya menguasai dan tidak memiliki kendaraan bermotor.

Sementara BBNKB dalam Undang-Undang PDRD dinyatakan sebagai pajak yang dikenakan orang pribadi atau badan yang menerima penyerahan hak milik kendaraan bermotor sebagai akibat perjanjian jual beli, tukar menukar, hibah, warisan, atau pemasukan ke badan usaha. Jadi dalam hal ini yang berkedudukan sebagai wajib pajak adalah pihak yang menerima penyerahan kendaraan bermotor.

Pemungutan PKB dan BBNKB menurut Pasal 6 Undang-Undang 
PDRD dikenakan tarif progresif bagi kepemilikan kendaraan kedua dan seterusnya, yang ketentuannya ditetapkan berdasarkan peraturan daerah. Sehingga menjadi kewajiban bagi daerah provinsi ysang memiliki kewenangan untuk melakukan pemungutan PKB dan BBNKB untuk membentuk peraturan daerah. Pemungutan kedua jenis pajak yang dikenakan kepada obyek pajak berupa kendaraan bermotor tersebut di Provinsi Bali diatur dalam Peraturan Daerah Provinsi Bali Nomor 1 Tahun 2011 tentang Pajak Daerah (selanjutnya disebut dengan Perda Pajak Daerah Provinsi Bali). Dalam Perda Pajak Daerah Provinsi Bali tersebut telah ditetapkan mengenai pengenaan tarif progresif bagi PKB dan BBNKB. Besaran tarif progresif yang dikenakan terhadap PKB diuraikan dalam ketentuan Pasal 7 Perda Pajak Daerah Provinsi Bali, sebagai berikut:

1. Bagi kendaraan pertama dikenakan sebesar $1,5 \%$;

2. Bagi kendaraan kedua dan selanjutnya dikenakan tarif progresif dengan peningkatan $0,5 \%$ sebagai berikut:

a. Kendaraan kepemilikan kedua sebesar $2 \%$;

b. Kendaraan kepemilikan ketiga sebesar 2,5\%;

c. Kendaraan kepemilikan keempat sebesar $3 \%$; dan

d. Kendaraan kepemilikan kelima dan seterusnya sebesar $3,5 \%$

Ketentuan pengenaan pajak progresif dalam Perda Pajak Derah Provinsi Bali selanjutnya diatur lebih lanjut dalam Pergub No. 40 Tahun 2011 selain menguraikan tentang jenis kendaraan yang terkena pajak progresif dan besar tarif pajak yang dikenakan, juga ditentukan mengenai dasar kepemilikan kendaraan bermotor untuk menentukan kendaraan kedua dan seterusnya. Hal ini dinyatakan dalam Pasal 4 ayat (4) Pergub No. 40 Tahun 2011 yaitu kepemilikan kendaraan bermotor didasarkan pada nama dan/atau alamat yang sama dalam satu keluarga yang dibuktikan dalam satu kartu keluarga.

Pengenaan tarif progresif bagi kendaraan roda empat sebagaimana diatur dalam Perda Pajak Daerah Provinsi Bali dan Pergub No. 40 Tahun 2011 diimplementasikan pada Juni 2014, padahal baik dalam Perda maupun Pergub pelaksanaan pajak progresif tersebut diamanatkan sejak kedua perundang-undangan tersebut diundangkan dalam Lembaran Daerah. Melalui hasil wawancara dengan Kepala Badan Pendapatan 
Daerah Provinsi Bali, hal tersebut disebabkan oleh upaya pendataan pemilik kendaraan bermotor di wilayah Provinsi Bali. Pengenaan pajak progresif dilakukan dengan membandingkan data kepemilikan kendaraan dengan kartu keluarga (KK), yang dalam pandangan pemerintah saat itu merupakan data yang paling akurat, serta mencegah terjadinya kebocoran pajak. ${ }^{19}$ Pelaksanaan pajak progresif yang awalnya hanya dikenakan kepada kendaraan roda empat saja menurut pendapat Putu Suka Redaya disebabkan karena penyebab utama kemacetan adalah kendaraan roda empat yang pertumbuhannya melebihi infrastruktur jalan yang ada. Selain itu masih adanya sikap skeptis dari masyarakat terhadap pengenaan pajak progresif bagi kendaraan bermotor tersebut, sehingga pemberlakuan pajak progresif bagi kendaraan roda empat merupakan bentuk sosialisasi dan uji coba kebijakan tersebut. Apabila dapat berlaku secara efektif baru dirancang pengenaan pajak progresif bagi kendaraan roda dua, sehingga dapat digunakan sebagai potensi penerimaan PKB dan BBNKB. ${ }^{20}$

Pengenaan pajak progresif yang berdasarkan kartu keluarga berarti urutan kendaraan bermotor yang dikenakan pajak sesuai nama yang tercantum pada kartu keluarga, tanpa memperhatikan nama dan/atau alamat pemilik kendaraan bermotor tersebut. Dengan demikian maka beban PKB yang dikenakan akan menjadi sangat besar apabila dalam satu keluarga terdapat lebih dari satu kendaraan roda empat, meskipun terdaftar kepemilikannya atas nama yang berbeda. Ketentuan pengenaan tarif progresif bagi PKB dan BBNKB berdasarkan Kartu Keluarga tersebut oleh masyarakat dirasa amat memberatkan, sehingga pelaksanaan ketentuan tersebut tidak efektif.

Tidak efektifnya pelaksanaan pajak progresif bagi kendaraan roda empat di Provinsi Bali juga disadari pemerintah setelah penerimaan pajak yang bersumber dari PKB dan BBNKB mengalami penurunan, tidak sesuai dengan tujuan awal kebijakan ini ditetapkan yaitu untuk meningkatkan PAD. Pendapatan pajak yang terakumulasi dari perolehan PKB dan BBNKB pada tahun 2014 dibandingkan tahun 2015 menunjukkan

${ }^{19}$ Hasil wawancara terhadap Kepala Bapenda Provinsi Bali, I Made Santha, yang dilakukan pada tanggal 2 Juli 2017.

${ }^{20}$ Berdasarkan hasil wawancara dengan Kepala UPT Bapenda Provinsi Bali di Kota Denpasar yang dilaksanakan penulis dengan narasumber pada 3 Agustus 2017. 
penurunan sebesar 12 milyar rupiah. Penurunan tersebut diakibatkan oleh rendahnya penerimaan BBNKB pasca diberlakukannya pajak progresif, serta menurunnya animo masyarakat dalam membayar PKB disebabkan paengenaan pajak progresif beradasarkan $\mathrm{KK}^{21} \mathrm{Hal}$ ini dapat ditunjukkan dengan tabel penerimaan PKB dan BBNKB pasca berlakunya pajak progresif tahun 2014 dan 2015 sebagai berikut:

Tabel 1

\section{Penerimaan PKB dan BBNKB di UPT Bapenda Provinsi Bali di Kota Denpasar \\ 2014-2015 22}

\begin{tabular}{|c|c|c|c|}
\hline Tahun & PKB & BBNKB & Jumlah \\
\hline 2014 & 360.403 .777 .650 & 417.292 .983 .400 & 777.696 .761 .050 \\
\hline 2015 & 391.284 .258 .225 & 374.581 .461 .900 & 765.865 .720 .125 \\
\hline
\end{tabular}

Penurunan jumlah penerimaan pajak ini selanjutnya menjadi bahan kajian dari Pemerintah Provinsi Bali. Hasil kajiannya menunjukkan bahwa kendala yang dihadapi atas pemberlakuan pajak progresif bagi kendaraan roda empat sehingga belum terlaksana efektif yaitu dasar pengenaan yang berdasarkan kartu keluarga memicu masuknyanya kendaraan plat luar Bali. Hal ini menurut Kadis Pendapatan Provinsi Bali, I Made Santha, apabila pendataan kendaraan roda empat didasarkan pada Kartu Keluarga maka banyak nama kedua di keluarga yang membeli kendaraan di luar daerah guna menghindari pajak progresif namun kendaraan tersebut digunakan di wilayah Provinsi Bali. ${ }^{23}$

Gubernur Bali, Made Mangku Pastika, juga menyatakan kelemahan penerapan pajak progresif berdasarkan Kartu Keluarga mengakibatkan banyak kendaraan berplat luar Bali yang beroperasi di Bali.

21 Berdasarkan hasil wawancara dengan Kepala UPT Bapenda Provinsi Bali di Kota Denpasar yang dilaksanakan penulis dengan narasumber pada 3 Agustus 2017.

${ }^{22}$ Data diperoleh berdasarkan hasil penelitian pada UPT Bapenda Provinsi Bali di Kota Denpasar.

23 Feri Kristianto, 2016, Pemerintah Bali akan Revisi Pajak Progresif Kendaraan, http://finansial.bisnis.com/read/20160303/10/524850/pemerintah-baliakan-revisi-pajak-progresif-kendaraan, diakses tanggal 28 Juli 2017. 
Kendaraan tersebut kepemilikannya orang Bali, menetap di Bali, serta menggunakan sarana infrastruktur di Bali, namun pajaknya tidak masuk ke Pemprov Bali. Hal ini mengakibatkan tidak optimalnya penerapan pajak progresif. Bahkan, terjadi potensi kehilangan pendapatan selama setahun penerimaan pajak progresif sebanyak 1.503 unit atau sebesar Rp. 2.273.794.200 yang akhirnya berdampak terhadap capaian pajak daerah saat ini. ${ }^{24}$

Efektivitas penerapan pajak progresif bagi kendaraan roda empat di Provinsi Bali berdasarkan keterangan segenap stakeholder tersebut dapat dikaji berdasarkan teori sistem hukum yang dikemukakan oleh Friedman. Beliau melalui teori sistem hukum menyatakan bahwa a legal sistem in actual operation is complexorganism in which structure, substance, and culture interact (sistem hukum dalam pelaksanaannya merupakan hal yang kompleks dimana struktur, substansi, dan budaya saling terkait. ${ }^{25} \mathrm{Hal}$ ini dapat dipahami bahwa bekerjanya hukum dalam suatu masyarakat merupakan keterkaitan antara struktur hukum, substansi hukum, dan budaya hukum. Bilamana terdapat kesalahan pada salah satu dari ketiga komponen tersebut, maka hukum tidak akan dapat bekerja di masyarakat.

Bekerjanya aturan hukum dalam masyarakat juga dikemukakan oleh Soerjono Soekanto. Dalam pandangan beliau terdapat 5 (lima) faktor yang berpengaruh dalam terlaksananya aturan hukum di masyarakat yaitu faktor hukumnya sendiri, penegak hukum, sarana atau fasilitas, masyarakat, dan kebudayaan. ${ }^{26}$ Serupa dengan pandangan Friedman, kelima factor yang dikemukakan Soerjono Soekanto saling berkaitan erat satu sama lain, sebab merupakan esensi dari penegakan hukum, juga merupakan tolak ukur dari efektivitas berlakunya undang-undang atau peraturan. Dengan demikian maka pandangan Soejono Soekanto hanyalah perluasan atas teori sistem hukum yang dikemukakan oleh Friedman.

Berdasarkan kedua pandangan ahli hukum tersebut, maka dapat

${ }^{24}$ Suara Dewata, 2016, Penerapan Pajak Progresif Tidak Optimal, https://suaradewata.com/read/2016/04/14/201604140025/PenerapanPajak-Progresif-Tak-Optimal.html, diakses tanggal 31 Juli 2017.

${ }^{25}$ Lawrence M. Friedman, Loc. Cit.

${ }^{26}$ Soerjono Soekanto, Op. Cit., hal. 15 
dikatakan bahwa tidak efektifnya penerapan aturan pajak progresif berdasarkan Perda Pajak Daerah Provinsi Bali yang lebih lanjut diatur dalam Pergub No. 40 Tahun 2011, disebabkan oleh aturan hukumnya sendiri (legal substance), serta budaya masyarakat (legal culture). Aturan hukum dalam Pergub No. 40 Tahun 2011 yang mendasarkan pengenaan pajak progresif kendaraan roda empat pada kartu keluarga dianggap terlalu memberatkan masyarakat, karena besarnya tarif pajak yang dikenakan terhadap kendaraan yang dimiliki oleh wajib pajak dalam satu keluarga. Beberapa wajib pajak yang diwawancarai mengatakan bahwa mereka amat terbebani oleh adanya pajak progresif berdasarkan KK, karena jumlah kendaraan bermotor yang dikenai pajak progresif menjadi amat banyak dan pajak yang dibayarkan amatlah besar. Oleh karena itu masyarakat kemudian mencari celah untuk menghindari kewajiban membayar pajak yang tinggi berdasarkan pajak progresif tersebut, dengan jalan membeli kendaraan bermotor di luar wilayah Bali agar tidak terkena pajak progresif meskipun kendaraan tersebut nantinya digunakan di Bali. ${ }^{27} \mathrm{Hal}$ ini tidak disadari masyarakat bahwa dengan pembelian kendaraan di luar Bali, maka BBNKB akan beralih menjadi hak pemerintah daerah tempat dibelinya kendaraan tersebut. Begitu pula dengan PKB yang dibayar setiap tahunnya, akan beralih menjadi milik pemerintah daerah lain meskipun menggunakan jalan di wilayah Provinsi Bali. Oleh karena itu dapat dikatakan bahwa factor aturan hukum dan budaya masyarakat lah yang menyebabkan pajak progresif ini tidak berjalan dengan efektif. Sementara pemerintah selaku stakeholder terkait telah berupa konsekuen menjalankan mekanisme yang disepakati guna mencapai tujuan kebijakan tersebut yaitu meningkatkan PAD Provinsi Bali.

Kendala-kendala yang terjadi pada saat implementasi pajak progresif di wilayah Provinsi Bali berkaitan dengan substansi hukum, masyarakat, dan budaya masyarakatnya selanjutkan dikaji oleh pemerintah dan menghasilkan rekomendasi dari pemerintah untuk mengubah ketentuan yang mengatur tentang pajak progresif baik dalam Perda Pajak Daerah Provinsi Bali maupun dalam Pergub No. 40 Tahun 2011. Dalam inisiatif pemerintah tersebut disampaikan bahwa hendaknya pengenaan 
pajak progresif yang berdasarkan kartu keluarga dialihkan menjadi berdasarkan pada Kartu Tanda Penduduk (KTP). Hal ini didasarkan atas pertimbangan bahwa dengan mendasarkan pada KTP pengenaan pajak progresif akan lebih fleksible dan tidak terlalu memberatkan masyarakat. ${ }^{28}$

Apabila pada awal penerapan pajak progresif jumlah PKB dan BBNKB menurun dari tahun sebelumnya, namun setelah dirubah dan dilaksanakan sejak Juni 2016 jumlah pendapatan dari PKB sudah mulai menunjukkan peningkatan jumlah penerimaan pajak. Adapun jumlah pendapatan PKB Provinsi Bali pada tahun 2014 sampai dengan tahun 2016 dapat ditunjukkan pada tabel berikut:

\section{Tabel 3}

\section{Penerimaan PKB dan BBNKB UPT Bapenda Provinsi Bali di Kota Denpasar}

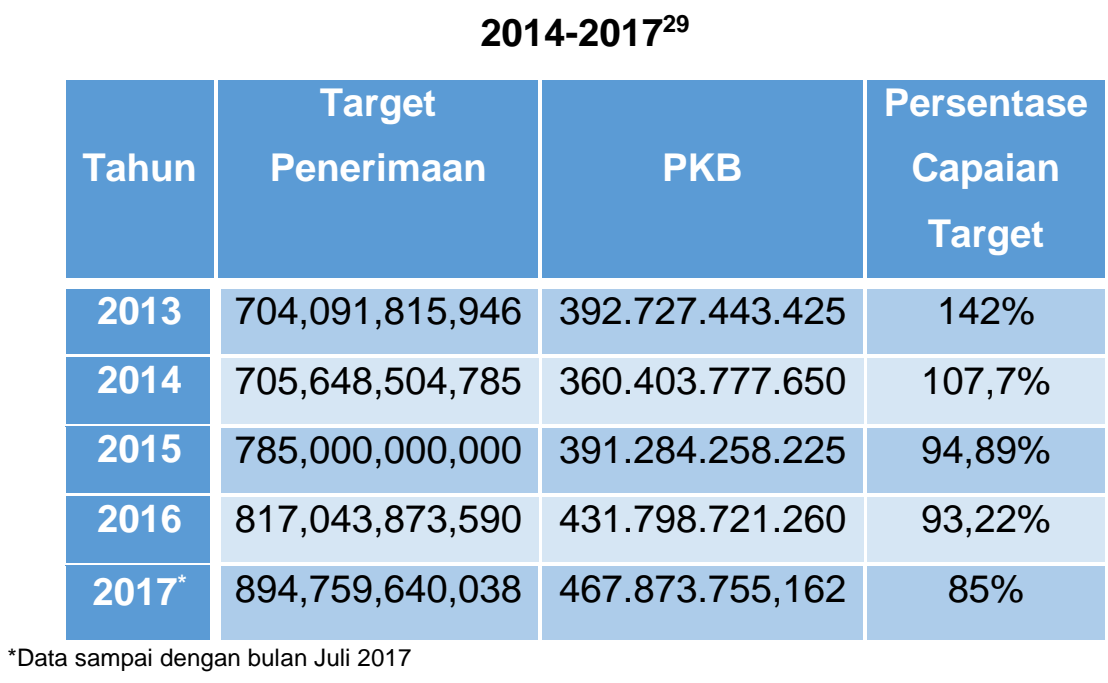

Data di atas menunjukkan besaran jumlah pendapatan daerah Provinsi Bali yang diperoleh dari PKB dan BBNKB, yang menjadi sumbangan terbesar bagi PAD Provinsi Bali. Dari data perolehan PKB tahun 2013 hingga 2017 dapat diketahui bahwa pada tahun 2014 PKB yang diperoleh mengalami penurunan dibandingkan tahun sebelumnya, yang disebabkan reaksi masyarakat menghindari pajak progresif kendaraan bermotor. Oleh karena itu pemerintah melakukan perubahan

${ }^{28}$ Hasil wawancara terhadap Kepala Bapenda Provinsi Bali, I Made Santha, yang dilakukan pada tanggal 2 Juli 2017.

${ }^{29}$ Data diperoleh berdasarkan hasil penelitian pada UPT Bapenda Provinsi Bali di Kota Denpasar. 
mengenai kebijakan pajak progresif kendaraan bermotor yang mampu meningkatkan penerimaan PKB di tahun-tahun berikutnya. Berbeda halnya dengan penerimaan BBNKB yang menurun tiap tahunnya yang menunjukkan bahwa minat pembelian kendaraan bermotor menurun di masyarakat. Hal ini merupakan tujuan utama pajak progresif kendaraan bermotor sebagai instrument untuk menekan laju pertumbuhan kendaraan bermotor.

\section{PENUTUP}

\section{Simpulan}

Berdasarkan uraian yang telah dipaparkan sebelumnya, maka terhadap rumusan masalah dikemukakan kesimpulan bahwa pemungutan pajak progresif bagi kendaraan bermotor di Provinsi Bali yang berlaku sejak pertengahan tahun 2014 berdampak bagi penerimaan daerah yang bersumber dari PKB dan BBNKB. Hal ini dapat ditunjukkan dengan menurunnya jumlah penerimaan PKB dan BBNKB pada tahun 2014 dibandingkan penerimaan pada tahun sebelum diberlakukannya pajak progresif kendaraan bermotor. Menurunnya penerimaan PKB dan BBNKB disebabkan oleh dasar pengenaan pajak yang dirasa terlalu berat bagi masyarakat sehingga daya beli masyarakat menurun, dan adanya upaya masyarakat menghindari pajak progresif dengan membeli kendaraan bermotor di luar Bali. Oleh karena itu dasar pengenaan pajak progresif kendaraan bermotor diubah menjadi berdasarkan KTP, sehingga lebih fleksibel dan tidak membebani masyarakat. Selain itu diubah pula mengenai besaran tarif pajak yang dikenakan kepada kendaraan bermotor, baik roda dua maupun roda empat. Berdasarkan perubahan-perubahan tersebut, saat ini penerimaan PKB dan BBNKB telah meningkat dibandingkan tahun sebelumnya.

\section{Saran}

Adapun saran yang disampaikan terkait dengan materi yang dikaji yaitu hendaknya pengenaan pajak progresif bagi kendaraan bermotor sebagai kebijakan publik yang berisi pembebanan negara kepada rakyat harus disusun dengan kajian mendalam sebelumnya, agar tidak terkesan sebagai uji coba regulasi dan lebih memberi nilai kepastian hukum. 
Sehingga kebijakan tersebut dapat berlaku efektif guna mencapai tujuan yang dikehendaki melalui kebijakan tersebut.

\section{DAFTAR PUSTAKA}

\section{Buku:}

Agustino, Leo, 2008, Dasar-Dasar Kebijakan Publik, Alfabeta, Bandung.

Bohari, 2016, Pengantar Hukum Pajak (Edisi Revisi), PT. Rajagrafindo Persada, Jakarta.

Friedman,Lawrence M., 1969, The Legal System: A Sosial Science Perspective. Russel Sage Foundation, New York.

Islamy, M. Irfan, 2009, Prinsip-Prinsip Perumusan Kebijaksanaan Negara, Bumi Aksara, Jakarta.

Marbun, SF \& Mahfud MD , Moh, 2006, Pokok-Pokok Hukum Administrasi

Negara, Liberty Yogyakarta.

Mardiasmo, 2013, Perpajakan(edisi revisi), CV. Andi Offset,Yogyakarta.

Marsyahrul,Tony, 2014, Pengantar Perpajakan, Grasindo, Jakarta.

Nurmantu,Safri, 2007, Pengantar Perpajakan, Edisi 3, Granit, Jakarta.

Soejono dan H.Abdurrahman, 2003, Metode Penelitian Hukum Cetakan Ke-2, PT. Rineka Cipta, Jakarta.

Soekanto, Soerjono, 2000, Penelitian Hukum Normatif: Suatu Tinjauan Singkat, edisi 1, cet.v, PT Raja Grafindo Persada, Jakarta.

Supramono dan Theresia Woro Damayanti, 2013, Perpajakan Indonesia, Mekanisme dan Perhitungannya, Andi Offset, Yogyakarta

Yani,Ahmad 2008, Hubungan Keuangan antara Pemerintah Pusat dan

Pemerintah Daerah di Indonesia, PT RajaGrafindo Persada, Jakarta.

Feri Kristianto, 2016, Pemerintah Bali akan Revisi Pajak Progresif Kendaraan,

http://finansial.bisnis.com/read/20160303/10/524850/pemerintah -bali-akan-revisi-pajak-progresif-kendaraan, diakses tanggal 28 Juli 2017.

Suara Dewata, 2016, Penerapan Pajak Progresif Tidak Optimal, https://suaradewata.com/read/2016/04/14/201604140025/Pener apan-Pajak-Progresif-Tak-Optimal.html, diakses tanggal 31 Juli 
2017.

\section{Peraturan Perundang-Undangan:}

Undang-undang Republik Indonesia Nomor 22 Tahun 2009 tentang Lalu Lintas dan Angkutan Jalan (Lembaran Negara Republik Indonesia Tahun 2009 Nomor 96, Tambahan Lembaran Negara Republik Indonesia Nomor 5025).

Undang-Undang Nomor 28 Tahun 2009 tentang Pajak Daerah dan Retribusi Daerah (Lembaran Negara Republik Indonesia Tahun 2009 Nomor 130, Tambahan Lembaran Negara Republik Indonesia Nomor 5049).

Peraturan Menteri Dalam Negeri Republik Indonesia Nomor 26 Tahun 2014 tentang Penghitungan Dasar Pengenaan Pajak Kendaraan Bermotor dan Bea Balik Nama Kendaraan Bermotor Tahun 2014 (Berita Negara Republik Indonesia Tahun 2014).

Peraturan Daerah Provinsi Bali Nomor 1 Tahun 2011 tentang Pajak Daerah (Lembaran Daerah Provinsi Bali Tahun 2011 Nomor 1, Tambahan Lembaran Daerah Propinsi Bali Nomor 1).

Peraturan Daerah Provinsi Bali Nomor 8 Tahun 2016 tentang Perubahan Kedua atas Peraturan Daerah Provinsi Bali Nomor 1 Tahun 2011 tentang Pajak Daerah (Lembaran Daerah Provinsi Bali Tahun 2016, Nomor 8, Tambahan Lembaran Daerah Provinsi Bali Nomor 7). 